\title{
THE EFFECT OF MANAGERIAL SKILLS, EDUCATION LEVEL, AND THE ROLE OF VILLAGE CONSULTATIVE BODY TOWARD THE PERFORMANCE OF VILLAGE HEAD: AN INDONESIAN CASE
}

\author{
Nurul Afifah ${ }^{1}$ \\ Email: nurulafifah141099@gmail.com \\ Dian Anita Nuswantara ${ }^{2}$ \\ Email: diananita@unesa.ac.id
}

\begin{abstract}
Researchers choose to research in Kabupaten Bojonegoro, because there were cases of misappropriation of village funds by the village head and there were cases of villages budget reporting to the head of local government. This study aims to look at the factors that can improve the performance of village heads in village finances. There are three independent variables tested, namely managerial ability, level of education, and the role of the Village Consultative Body (BPD), while the dependent variable in this study is the performance of village financial management. This study took a setting in Kabupaten Bojonegoro by taking a sample of village heads in 6 (six) sub-districts that received the largest village funds. The type of data used in this study is primary data collected through distributing questionnaires to respondents. The distribution of the questionnaire was carried out by meet the village head directly at the village head's office, attend the village head forum, and send the questionnaire link via Whatsapp media. They are 150 samples collected through the purposive sampling technique. The data analysis technique used multiple linear regression with the SPSS 23 application program. The test results showed that the managerial ability and the role of the BPD had a significant effect on the village head's performance, while the level of education did not affect the performance of the village head.
\end{abstract}

Keywords: Managerial skills, Level of education, The role of BPD, Performance, Head of village

\section{INTRODUCTION}

In Law No. 6/2014 on Villages, the government has positioned the village as the end of development and improvement of community welfare. Based on this stipulation, the central government gives the village authority to manage their own households according to their potential to be able to create community welfare. Since 2015 the central government has disbursed large funds for villages, amounting to IDR

\footnotetext{
${ }^{1}$ Corresponding author: Univesitas Negeri Surabaya, JL. Ketintang, Gayungan, Surabaya

${ }^{2}$ Univesitas Negeri Surabaya, JL. Ketintang, Gayungan, Surabaya
} 
20.7 trillion, with a distribution of IDR 280 million for each village and continues to this day (djkp.kemenkeu.go.id 2017). From the amount of funds, good financial management is needed so that every program carried out by the village government can be realized, this is very dependent on the performance of the village head.

According to Prawirosentono in (Utami 2012) performance is the result of work that has been achieved by individuals or groups in an organization, which is in accordance with the duties and responsibilities of each individual to achieve the goals of the organization concerned legally, does not violate the law and is in accordance with ethics and morals. According to Vroom's Expectation Theory, performance is influenced by individual factors such as skills, personality, experience, abilities and knowledge. Vroom's Expectation Theory uses three variables: Expectancy, Instrumentality, and Valence. Hope is an individual's belief that the effort made is able to produce good and maximum performance. However, the variable expectations are influenced by three factors, namely skills, resources, and motivation or support. The relevance of this research lies in the variable expectations which are relevant to Prof. Siswoyo $(2018,13)$ individual performance is the result of performance influenced by competence, management and organizational support.

According to Vroom's Expectation Theory, skills are the ability to get work done effectively. This definition shows that as an organizer of village governance, the Village Head must be able to carry out development, community development and community empowerment, so that he requires managerial skills (Kuengo, Posumah, and Dengo 2017) Then the resources referred to in Vroom's Expectation theory are defined as the potential that a person has in doing work, by having the right resources so that they can do the job well. According to Ariono (2017), the existence of quality human resources and high education can affect the performance of village heads in managing village finances, including submitting reports on the realization of the APBDes implementation to the Regent. This is relevant to the research of Jatmiko (2014) which states that the delay in reporting the APBDes is partly due to the low level of education of village heads.

However, based on the data, the majority of education owned by village heads in Bojonegoro Regency has graduated from high school / high school equivalents, which is around 273 village heads, as seen in the following graph:

Graph 1. Village Head Education Data for 2019

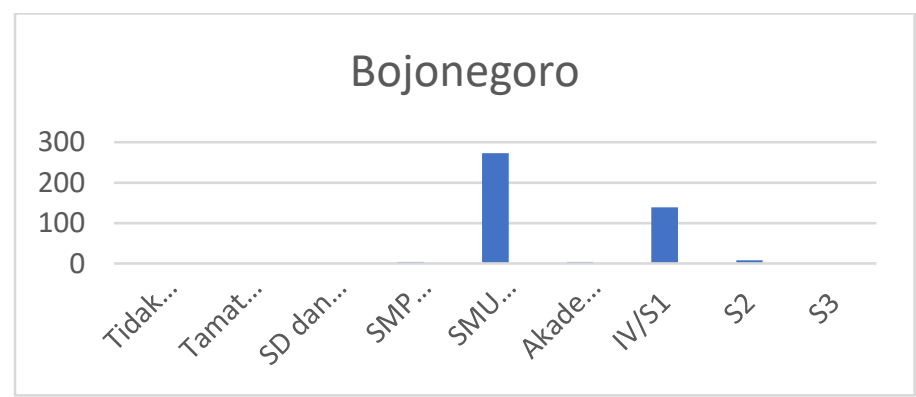

Source: (jatim.bps.go.id 2019)

Graph 1 shows that the education of the village head is sufficient, due to the qualifications of a candidate for village head, namely having a junior high school (SMP) education, as stated in the Bojonegoro Regency Regulation No. 13 of 2015 
article 25. However, based on their duties and functions as leaders, village heads must have the ability to make decisions (Onibola, Kiyai, and Laloma 2017). This ability at the level of the Indonesian National Qualifications Framework (KKNI) belongs to the 7th qualification, namely graduates of professional education (S1, S2, and S3).

The performance of the village head is not only influenced by education and skills, but also by support and motivation. According to Vroom's Expectation Theory, support is guidance and supervision provided by colleagues who are in charge of overseeing the efficiency and quality of the work that has been done. The division that has a duty as a companion in running the village government and has the function of overseeing the performance of the village head in managing village finances is the Village Consultative Body (BPD). The Village Consultative Body does not need to worry in carrying out its function of overseeing the performance of the village head in managing village finances because there is a clear legal basis. If the role of the BPD is functioning properly, the check and balance mechanism will function to prevent misuse of village finances by village heads (Roza and Arliman 2014). Even so, until now there are still many criminal acts of corruption occurring, including in Bojonegoro Regency. Namely, there were two village heads who committed corruption crimes against village funds amounting to IDR 1 billion (tribunnews.com 2019).

The above phenomenon shows that even though there is a check and balance mechanism, empirical facts show that the performance of village heads is still low, even tinged with misappropriation of village funds. Based on the above theories and phenomena, the researcher is interested in conducting research to determine the variables that affect the performance of the village head in carrying out the function of village financial management in Bojonegoro Regency.

\section{LITERATURE REVIEW AND HYPOTHESIS DEVELOPMENT 2.1 Financial Management Performance of Village Head}

Ministry of Home Affairs Regulation No. 113 of 2014 concerning village financial management, article 2 paragraph 1, states that village financial management is based on transparent, accountable, participatory principles and is carried out in an orderly and disciplined budget. The performance of the Village Head in managing village finances will determine whether the goals of village funds are realized or not (Munti and Fahlevi 2017). So the village government, especially the village head, has the responsibility for managing village finances, which is carried out effectively to be able to carry out development that is on target and efficiently (Siregar and Syam 2017).

Therefore, measuring the performance of village heads in the field of village financial management is a means of assessing organizational success and can also be used as a basis for preparing rewards or as a basis for determining organizational strategies in order to create good governance (Rempowatu and Tirayoh 2016). Performance measurement is defined as the process of translating, monitoring and using objective indicators of organizational and program performance on a regular basis, or controlling organizational activities as a means of ensuring that the organization is able to achieve its stated goals (Neely et al. (2006); Poister (2003)). The purpose of performance measurement can be used to assess organizational success and can also be used as a basis for preparing rewards or as a basis for determining organizational strategies in order to create good governance (Rempowatu and Tirayoh 2016) 
In Indonesia, indicators for measuring government financial performance are seen from value for money, namely the concept of managing public sector organizations based on three main elements, namely economy, efficiency and effectiveness (Mardiasmo 2016, 130). The application of these principles will result in regional financial management that truly reflects the interests and expectations of the local community in an economical, efficient, effective, transparent and responsible manner (Tambuwun, Pangemanan, and Afandi 2014). The measurement of each indicator from the value for money concept is as follows:

1) Economic Measurement

The economic concept is closely related to the concept of the cost of obtaining input. Economy means that input resources should be obtained at a lower price (spending less), namely prices that are close to market prices (Nordiawan and Hertianti 2010, 160). Mathematically, the economy is a comparison between input and input value. The input in this case is the budget target, while the input value is the realization of the budget.

2) Efficiency Measurement

Efficiency is the relationship between goods and services (output) resulting from an activity with the input resources used (Nordiawan and Hertianti 2010, 160). The greater the output produced compared to the input used, the greater the level of efficiency of an organization.

3) Effectiveness Measurement

Effectiveness is basically the level of achievement of the results of a program or activity with predetermined targets. Effectiveness is the relationship between output and objectives. A public sector organization can be said to be effective if the organization can achieve its stated goals.

\subsection{Vroom's Expectancy Theory}

Vroom's Expectation Theory was put forward by Victor. H. Vroom (1964) in his book entitled "Work and Motivation". According to this theory, someone will be motivated to carry out a certain activity because they want to achieve the desired goal. According to Vroom, employee performance is influenced by individual factors, such as skills, personality, experience, abilities and knowledge. Vroom's theory has 3 variables, namely:

\section{Expentacy}

Namely a person's self-confidence that every effort made will result in good and maximum performance, the higher one's effort, the higher the resulting performance. This variable of expectation is influenced by several factors, namely:

a. Skills: the ability of a person to be able to complete work effectively

b. Resources: have the potential in accordance with the task at hand

c. Support: guidance or support obtained from colleagues and task supervisors that determines the efficiency and quality of tasks.

2. Instrumentality (Instrumentality)

Instrumentality is a person's belief that the performance that has been done will get a certain result, such as a salary increase, promotion, bonus, intensive, etc.

3. Valency (Valency) 
Valency is the importance or value given to someone because of a task that has been completed. Valence is influenced by several factors such as desire, the results to be achieved.

Based on Vroom's expectancy theory, this study examine 1 (one) element, namely expectations with 3 (three) factors, namely managerial skills, resource potential and support.

\section{Managerial Skills}

Managerial performance according to Stoner in (Saputra 2015) is how effective and efficient managers are in working to achieve organizational goals. Then the statement is in accordance with previous research that the village head has the responsibility for managing village finances effectively and efficiently. Managerial performance is related to Henry Fayol's managerial activities which include management functions (Lengkong 2018):

1) Planning, namely activities to determine the steps that can be used by the organization in achieving goals.

2) Organizing, namely adjusting activities owned resources to achieve organizational goals.

3) Direction, namely the activity of providing direction to employees by means of motivation, communication and leadership to be able to produce good performance, in order to achieve the goals of the organization.

4) Coordinating, namely coordinating activities carried out through good communication.

5) Control, namely the activity of ensuring that all activities that have been management have been completed.

Managerial activities proposed by Henry Fayol are relevant to managerial abilities as stated by Siagian P. Sondang in Lengkong (2018). Managerial ability is the ability used to manage businesses such as planning, organizing, monitoring and assessment. In accordance with the duties to organize village government, carry out development, community development and community empowerment, for this reason, village heads need to have managerial abilities (Kuengo, Posumah, and Dengo 2017).

\section{Resources potential and education level}

Human resources need to have certain education in order to carry out their duties properly. Education is defined as formal education that has been achieved while in school. According to Mangkunegara in (Rofikoh and Budiarti 2019) the level of education is a process that is carried out in the long term, and uses organized and systematic procedures, usually used by managerial staff to acquire and learn knowledge. Hastin and Jaya have a perspective (Kusmiyatinningsih 2017) that in order to get employees who have good and quality performance, understand their duties, they must have employees who are equipped with education according to their duties and functions.

3. Support and role of Village Consultative Body (BPD)

Support for the performance of the village head can be in the form of guidance from colleagues and task supervisors who determine the efficiency and quality of tasks. According to Permendagri No. 113 of 2014, Village Consultative Body is an agency that has responsibility for government administration, which channels the aspirations of the community. In addition, Village Consultative Body has a very important role as stated in Permendagri No. 110 of 2016, namely overseeing 
the performance of the village head (bulelengkab.go.id 2019). In carrying out its supervisory function, the Village Consultative Body monitors the performance of the village head from all aspects of village administration. Of all these aspects, village finances are a top priority because they are prone to fraud (Widiastutiningrum 2017).

\subsection{Hypotheses Development}

1. Managerial Skills and Financial Management Performance of Village Head

Managerial skills are related to leadership. This ability is needed by managers to be able to direct employees to remain in the process of achieving goals. According to Vroom's Expectation Theory to produce maximum performance for an individual requires a skill. Because as the administrator of the village administration, the village head must be able to provide direction to village officials so that the implementation of village governance runs well and financial management is carried out in a transparent and accountable manner. So that he needs to have managerial skills (Kuengo, Posumah, and Dengo 2017). This opinion is relevant to the research conducted (Lengkong 2018) which states that a leader needs to have managerial abilities, in order to be more innovative and creative in achieving organizational goals. H1: Managerial skills has a positive effect on financial management performance of village head

\section{Education Level and Financial Management Performance of Village Head}

Human resources need to have certain education in order to carry out their duties properly. Education is defined as formal education that has been achieved while in school. According to Handoko in (Ariono 2017) formal education is the capital needed by individuals, in order to have the knowledge needed to carry out tasks and be able to develop their potential according to their fields. Therefore, the village head needs to have adequate education to carry out his duties and obligations in providing services and welfare to the community through good village financial management in accordance with the principle of value for money. Then the level of education will affect the performance of the village head, as stated in the study (Ariono 2017) that the higher the level of education of a person will affect his performance. Which is shown by the results of his research, that the level of education has a positive and significant effect on the performance of village officials.

H2: Education Level has a positive effect on financial management performance of village

\section{Village Consultative Body Role and Financial Management Performance of Village Head}

According to Vroom's Expectation Theory, a person's performance is affected by the support one gets from guidance provided by colleagues and the task supervisory body. So in the village administration, as the monitoring body for the performance of the village head, the Village Consultative Body must monitor every activity carried out by the village head to reduce the mode or abuse of village authority and finances. If the supervision function of the Village Consultative Body is carried out properly, then the performance of the village head will be better. This is relevant to the results of research (Adha 2019), namely Village Consultative Body supervision has a positive and significant effect on the performance of village heads in development. 
H3: Village Consultative Body has a positive effect on financial management performance of village head.

\section{RESEARCH METHODS}

This study uses primary data, which is collected by distributing questionnaires to the Village Head in Bojonegoro Regency who is in the sub-district with the largest village fund receipts. Researchers chose to do research in Bojonegoro Regency because there were cases of misappropriation of village funds by village heads and cases of delays in reporting APBDes in 18 villages to the Regent of Bojonegoro Regency. This shows that the performance of the village head in managing village finances is poor (Justar, Kamaluddin, and Aljurida 2020). The measurement of the variables used in this study is the Likert interval scale of 1 to 5 . Number 5 has the category of strongly agree to number 1 , which is the category of strongly disagree.

The population in this study were 419 village heads in Bojonegoro Regency. In determining the sample of this study using non probability sampling with purposive technique. The criteria used in selecting the sample were: being in the sub-district that cumulatively received the largest amount of village funds in Bojonegoro Regency because the recipients of large amounts of village funds were identical with large responsibilities. Thus the sub-districts that received the largest village funds from the local government included Kepohbaru, Baureno, Kanor, Sumberrejo, Balen and Kapas sub-districts, with a sample size of 150 village heads. The questionnaire distribution technique carried out by researchers is offline and online distribution.

Offline distribution is carried out by visiting each village office spread across 6 sub-districts, while online distribution is carried out by sending a questionnaire link via Whatsapp media. The distribution process to data collection was carried out for 29 days, starting from March 1, 2021 to March 29, 2021. The data analysis technique used in this study was multiple linear regression analysis, with the following regression equation:

Where in:

$$
Y=a+b_{1} X_{1}+b_{2} X_{2}+b_{3} X_{3}+e_{i}
$$

Y : Head of Village Performance

a : Constant

$b_{1} \ldots b_{3}:$ Regression Coeefficient

$\mathrm{X}_{1} \quad$ : Managerial Skill

$\mathrm{X}_{2} \quad$ : Education Level

$\mathrm{X}_{3}$ : Village Consultative Body (BPD) Role

e : Error

\section{Research Variable \\ Managerial Skill (x1)}

Quoting the explanation of Professor Siagian P. Sondang in Lengkong (2018) managerial ability is the ability that an individual must have in managing a business or organization, consisting of planning, organizing, monitoring, and assessing so that the company can achieve the desired goals. Managerial ability indicators, namely:

1. Planning

2. Organizing

3. Monitoring

4. Evaluation 


\section{Education Level ( $\mathbf{x} 2)$}

Mangkunegara defines the level of education as a process carried out with a long time, which uses systematic procedures, and is usually used by managerial personnel to acquire certain knowledge, in order to achieve the desired goals (in Rofikoh and Budiarti 2019).

\section{Village Consultative Body (BPD) Role ( $\left.\mathbf{x}_{3}\right)$}

Ministry of Home Affairs Regulation No. 113 of 2014 explains that the Village Consultative Body (BPD) is an agency that has responsibility for the implementation of village government, and serves as a forum for aspirations from the community. Agreeing with this definition, Munti \& Fahlevi (2017) added that the BPD is a body that accommodates people's aspirations as well as a forum for the implementation of Pancasila democracy. In its implementation, according to the Minister of Home Affairs Regulation Number 110 of 2016 concerning the Village Consultative Body (BPD) states that the BPD has an important role in the village government, namely overseeing the performance of village heads including the financial aspects. Therefore, the indicator for the role of the BPD is the quality of supervision.

\section{Financial Management Performance of Village Head (Y)}

The performance of village financial management is the result of work carried out by village officials in carrying out all village financial management activities, starting from implementation planning, reporting, and village financial accountability (Munti and Fahlevi 2017). Several studies in the public sector have used the concept of value for money in measuring government financial performance Kurrohman (2013), Liando, Saerang and Elim (2014), Putra and Wirawati (2015), Ropa (2016). Their research results indicate that performance measurement with the concept of value for money has been able to measure financial performance in the local government sector. Therefore, the village financial management performance indicators in this study use the concept of value for money, namely economy, efficiency and effectiveness.

\section{RESULTS AND DISCUSSION \\ 4.1 Descriptive Statistic}

The measurement results of the managerial ability variable, the minimum answer to the respondent is 46 and the maximum answer is 70 with an average answer of 62.4 and a standard deviation of 4.8. For the education level variable, the minimum answer for the respondent is 2 and the maximum answer is 4 with an average answer of 3.3 and a standard deviation of 0.5 . The BPD role variable has a minimum answer of 18 and a maximum answer of 30 with an average answer of 25.9 and a standard deviation of 2.5. For the village head's performance variable in village financial management, the minimum answer for respondents is 22 and the maximum answer is 45 with an average answer of 39.9 and a standard deviation of 3.1 .

\subsection{Quality Data Test}

The quality test of the research instrument was carried out by using validity and reliability testing. If the significance value $<0.05$ and the r-table value $>$ r-table, the research instrument is valid. If the Cronbach Alpha value is $\geq 0.70$, then the research instrument is reliable. The results of the validity and reliability test on the 
instrument in this study have met the requirements so that this research instrument is said to be valid and reliable with a significance value on each question $<5 \%$ or 0.05 and the value of r-count $>$ r-table, namely $1.97635>0.4227$. Then the Cronbach Alpha value in the managerial ability variable was 0.927 , the Village Consultative Body role variable and financial management performance had a Cronbach Alpha value of 0.912 and 0.938 .

\subsection{Classical Assumption Test}

This study tested the classical assumptions consisting of normality, multicollinearity, and heteroscedasticity. Normality testing is used to see whether the residual value is normally distributed or not. A regression model is declared good if the residual value is normally distributed (Sugiyono 2015). Based on the normality test conducted, the data of this study were normally distributed with a significance value or probability of 0.080 . The multicollinearity test in this study also met the tolerance requirements $>0.10$ and variance inflation factor (VIF) $<10.00$, namely the managerial ability variable of 0.688 and 1.454 , while the education level variable had tolerance and VIF values of 0.981 and 1.019. And the BPD role variable has tolerance and VIF values of 0.682 and 1.466. Meanwhile, the results of the heteroscedasticity test showed that there was no heteroscedasticity in the regression model used.

\subsection{Hypothesis Testing}

The value of the coefficient of determination $\left(\mathrm{R}^{2}\right)$ has a value of 0 to 1 which states that the higher the value obtained, it shows that the information provided by the independent variable has a high prediction of the dependent variable.

Table 1. coefficient of determination

\begin{tabular}{ccccc}
\hline Model & $\mathrm{R}$ & $\begin{array}{c}\mathrm{R} \\
\text { Square }\end{array}$ & $\begin{array}{c}\text { Adjusted } \\
\mathrm{R} \\
\text { Square }\end{array}$ & $\begin{array}{c}\text { Std. } \\
\text { Error of } \\
\text { the } \\
\text { Estimate }\end{array}$ \\
\hline 1 & $0,675^{\mathrm{a}}$ & 0,455 &, 444 & 2,37239 \\
\hline
\end{tabular}

The results of the coefficient test as presented in table 1 above, show the value of $\mathrm{R}$ Square or $\mathrm{R}^{2}$, which is 0.455 . This value means that the independent variable consisting of managerial ability, level of education and the role of the BPD can explain the performance variable of the village head by $44.4 \%$. Meanwhile, $55.6 \%$ was influenced by other variables which were not examined in this study.

\subsection{F-test}

The F test is carried out to test whether there is an effect of the independent variable simultaneously on the dependent variable. The criteria used in decision making in this $F$ test are if the significance value is $<0.05$, then all independent variables simultaneously affect the dependent variable. 
Table 2. F-test (Simultaneous)

\begin{tabular}{cccccc}
\hline Model & $\begin{array}{c}\text { Sum of } \\
\text { Squares }\end{array}$ & df & $\begin{array}{c}\text { Mean } \\
\text { Square }\end{array}$ & F & Sig. \\
\hline $\begin{array}{c}1 \\
\text { Regression }\end{array}$ & 687,219 & 3 & 229,073 & 40,701 & $\begin{array}{c}, 00 \\
0^{\mathrm{b}}\end{array}$ \\
\hline Residual & 821,721 & 146 & 5,628 & & \\
\hline Total & 1508,940 & 149 & & & \\
\hline
\end{tabular}

Based on table 2 above, it can be seen that the significant value is less than

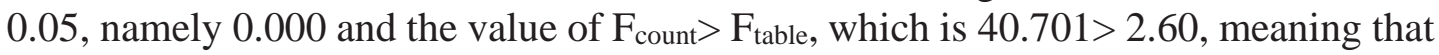
there is a simultaneous or joint influence on the independent variable on the dependent variable, namely managerial ability, level BPD role education has a simultaneous influence on the performance of village heads in village financial management.

\subsection{T-test}

The t-test is one of the hypothesis tests included in simple and multiple linear regression analysis. This test aims to determine the effect of the independent variable (X) partially on the dependent variable (Y). The results of the $t$ statistical test can be seen in the following table:

Table 3. T-test (Partial)

\begin{tabular}{lcc}
\hline \multicolumn{1}{c}{ Model } & $\mathbf{t}$ & Sig. \\
\hline \multicolumn{1}{c}{$\mathbf{1}$ (konstanta) } & 3,616 &, 000 \\
\hline Managerial skills & 5,550 & 0,000 \\
\hline Education level & 1,037 & 0,301 \\
\hline BPD role & 4,811 & 0,000 \\
\hline
\end{tabular}

Table 3 above shows the results of the t test on the managerial ability variable with a sig $<0.050$, which is 0.000 and the $t$-count $>t$-table value of 5,550> 1.976 , so that $\mathrm{H} 1$ is accepted, meaning that managerial ability has a significant effect on the performance of the village head in village financial management. Then for the variable level of education, the value of sig $>0.05$ is obtained, which is equal to 0.301 and the value of $\mathrm{t}$-count $<\mathrm{t}$-table value is $1.037<1976$, then $\mathrm{H} 2$ is rejected. This means that the level of education does not have a significant effect on the performance of the village head in managing village finances. Furthermore, for the role of the BPD variable, it has a sig $<0.05$, which is 0,000 and the tcount $>$ ttable value is $4.811>1.976$, so H3 is accepted, which means that the role of BPD has a significant effect on the performance of the village head in village financial management

\subsection{Discussion}

\section{Managerial Skills Affect The Performance Of The Village Head}

Based on the results of the first hypothesis test, the results obtained a significance value $<0.05$, namely 0.000 , so that $\mathrm{H} 1$ was accepted, meaning that managerial ability had an effect on the performance of the village head in village financial management. According to Vroom's Expectation Theory to produce maximum performance for an individual requires a skill. Because as the administrator of the village administration, the village head must be able to provide direction to the village apparatus so that the implementation of the village government runs well, and 
financial management is carried out in a transparent and accountable manner. So he needs to have managerial skills in order to be able to manage every activity in village government, especially in village financial management (Kuengo, Posumah, and Dengo 2017). In the managerial ability variable, the X1.2 indicator, which is the organizational indicator, has a mean value of 22.2 from a maximum value of 25 , the $\mathrm{X} 1.1$ indicator, which is planning, has a mean value of 13.6 from the maximum value of 15 , the X1.3 indicator is supervision. has a mean value of 13.2 from a maximum value of 15, and the X1.4 indicator, namely the assessment has a mean value of 13.1 from a maximum value of 15 . This indicates that the organizing indicator makes a major contribution in managing village finances. So in an organization if the manager has good organizational skills, it will produce good organizational performance as well.

\section{The Level of Education Has No Effect on the Performance of the Village Head}

Based on the results of testing the second hypothesis, it gets a significance value $>0.05$, namely 0.301 , so that $\mathrm{H} 2$ is rejected. This means that the level of education has no effect on the performance of the village head in managing village finances. Because whatever the education level of the village head does not affect his performance, there are several factors that may also influence, namely, (1) There is an opportunity for the village head to appoint honorary staff to help manage village finances, as stated in Government Regulation Number 49 of 2018 article 4 paragraph 5 concerning Government Employee Management with a Work Agreement which states that:

"The government's need for contract labor or honoraria has been determined by the Minister after a financial review and discussion with the Head of BKN is carried out."

(2) There is training or Bimtek to improve the capacity of village heads in managing village finances, such as Bimtek held by the Development and Regional Government Financial Management Development Institute (LPMKP2D) on the leadership of village heads in improving village development and training to increase the capacity of village government officials. Through this training, it is hoped that it can improve the performance of village heads in managing village finances so that they can work effectively, efficiently and be able to face global challenges. This is relevant to research (Triseptya and Hatta 2018) which states that training has a positive effect on the performance of village treasurers, with training it is expected to improve the performance of village treasurers to put more effort into developing financial management. So whatever educational level the village head has does not affect his performance, this statement is also relevant to the research conducted by Mandang, Lumanauw, and Walangitan (2017) stating that the level of education has no effect on performance, because with various levels of education, a person will remain do the job optimally so that its performance increases. While the results of this study contradict research (Wahyuni 2016) which states that the level of education has a significant effect on employee performance.

\section{The Role of the Village Consultative Body (BPD) Affects the Performance of the Village Head}

Based on the results of the third hypothesis test, the results obtained a significance value $<0.05$, namely 0.000 so that $\mathrm{H} 3$ is accepted. This means that the 
role of the BPD affects the performance of the village head in managing village finances. According to Vroom's Expectation Theory, a person's performance is affected by the support one gets from guidance provided by colleagues and the task supervisory body. So in the village administration, as the monitoring body for the performance of the village head, the BPD must monitor every activity carried out by the village head in order to reduce the existence of modus operandi or abuse of village authority and finances. If the supervision function of the BPD is carried out properly, then the performance of the village head will be better. This is relevant to the results of research (Adha 2019) namely that BPD supervision has a positive and significant effect on the performance of village heads in village development. In the variable of the role of the BPD, an indicator is the quality of supervision, which has a mean value of 25.9 from the maximum value of 30 . So in village governance, the quality of supervision carried out by the Village Consultative Body (BPD) can result in good village head performance. Good quality of supervision is shown by the implementation of routine monitoring of the performance of village heads and meeting objective supervisory standards in accordance with Permendagri Number 73 of 2020 concerning Supervision of Village Financial Management.

\section{CONCLUSIONS, LIMITATIONS, AND SUGGESTIONS}

Based on the results of the analysis regarding the effect of the performance of the village head using three variables, namely managerial ability, education level, and the role of the BPD based on Vroom's Expectation Theory, it can be concluded that the managerial ability and the role of the BPD have a significant effect on the performance of the village head in village financial management, but the level of education does not have a significant effect on the performance of the village head in managing village finances. Whatever the education level of the village head does not affect his performance in managing village finances, there are several factors that may also influence, namely (1) There is an opportunity for the village head to appoint honorary staff to help manage village finances and, (2) There is training or Bimtek to support capacity building village head, the role of the BPD has a significant effect on the performance of the village head in village financial management, as well as managerial ability, education level and the role of the BPD simultaneously have a significant effect on the performance of the village head in village financial management.

Two variables that have a significant effect can provide input for local governments in the formulation of village head empowerment programs, for example by increasing managerial abilities through managerial and leadership training. Local governments also need to increase the role of the BPD to improve the performance of village heads in financial management. For future researchers, other factors that are thought to have an influence on the performance of the village head have not been disclosed, for example the effectiveness of technical guidance and seconded accounting experts.

Even though, compared to secondary data, primary data collection spent more time and money. In that, the number of respondents may not sufficient enough to represent the population. The samples were limit to 6 districts, which only have the object of the village head. For further research, village officials who have a direct role in managing village finances can take the object. To interpret this study, we have to 
consider that these results are generated under certain conditions as mentioned in the purposive criteria.

\section{REFERENCES}

Adha, Ari Hanafi. 2019. "Pengaruh Pengawasan Badan Permusyawaratan Desa (BPD) Terhadap Kinerja Kepala Desa Dalam Pembangunan Desa Rambah Utama Kecamatan Rambah Samo Kabupaten Rokan Hulu." Journal of Chemical Information and Modeling 53 (9): 1689-99. https://www.neliti.com/publications/206054/pengaruh-pengawasan-badanpermusyawaratan-desa-bpd-terhadap-kinerja-kepala-desa.

Ariono, Imam. 2017. “Analisa Pengaruh Tingkat Pendidikan, Masa Kerja Dan Motivasi Kerja Terhadap Kinerja Perangkat Desa Di Kecamatan Kaliwiro Wonosobo." Jurnal Penelitian Dan Pengabdian Kepada Masyarakat UNSIQ 4 (3): 254-67. https://doi.org/10.32699/ppkm.v4i3.430.

bulelengkab.go.id. 2019. "Tugas Dan Fungsi BPD(Badan Pengawas Desa).” Website $\begin{array}{llll}\text { Resmi Pemerintah } & \text { Kabupaten }\end{array}$ https://www.bulelengkab.go.id/detail/artikel/tugas-dan-fungsi-bpdbadanpengawas-desa-45.

djkp.kemenkeu.go.id. 2017. "Perubahan Rincian Dana Desa Menurut Daerah Kabupaten/Kota Tahun Anggaran 2018." Kementrian Keuangan Direktorat Jenderal Perimbangan Keuangan. 2017. http://www.djpk.kemenkeu.go.id/?p=5800.

Haryono, Siswoyo. 2018. Manajemen Kinerja SDM Teori Dan Aplikasi. http://library1.nida.ac.th/termpaper6/sd/2554/19755.pdf.

jatim.bps.go.id. 2019. "Tingkat Pendidikan Tertinggi Yang Diutamakan Kepala Desa/Lurah Di Jawa Timur." BPS Provinsi Jawa Timur. 2019. https://jatim.bps.go.id/statictable/2019/10/10/1795/banyaknya-desa-kelurahanmenurut-tingkat-pendidikan-tertinggi-yang-diutamakan-kepala-desa-lurah2018-.html.

Jatmiko, Udik. 2014. “Analisis Faktor-Faktor Yang Menyebabkan Keterlambatan Pelaporan Pertanggungjawaban Keuangan Pemerintah Desa Paron Kecamatan Ngasem Kabupaten Kediri Udik Jatmiko," no. 113.

Justar, Andi Jusriadi, Laode Amijaya Kamaluddin, and A.M Azhar Aljurida. 2020. "Kualitas Kepemimpinan Kepala Desa Dalam Pembangunan Di Desa Erabaru Kecamatan Tellulimpoe Kabupaten Sinjai" 2 (1).

Kuengo, Syahrul, Johnny Hanny Posumah, and Salmin Dengo. 2017. "Kompetensi Kepala Desa Dalam Penyelenggaraan Pemerintahan Di Desa Tounelet Kecamatan Kakas Kabupaten Minahasa.” Jurnal Administrasi Publik UNSRAT 3 (046).

Kurrohman, Taufik. 2013. "Evaluasi Penganggaran Berbasis Kinerja Melalui Kinerja Keuangan Yang Berbasis Value For Money Di Kabupaten/Kota Di Jawa Timur.” Jurnal Dinamika Akuntansi 5 (1): 1-11.

Kusmiyatinningsih, Novi. 2017. Pengaruh Tingkat Pendidikan, Kepemimpinan, Dan Teknologi Informasi Terhadap Kinerja Perangkat Desa Se Kecamatan Paguyangan Kabupaten Brebes. Lib.Unnes.Ac.Id. Vol. 1. http://lib.unnes.ac.id/id/eprint/29874. 
Lengkong, Degrey U. 2018. "Kemampuan Manajerial Camat Terhadap Kinerja Pegawai Di Kecamatan Aertembaga Kota Bitung, Pembimbing." Ejournal.Unsrat.Ac.Id, no. April.

Liando, Harry Saputra, David Paul Elia Saerang, and Inggriani Elim. 2014. "Analisis Kinerja Keuangan Pemerintah Kabupaten Kepulauan Sangihe Menggunakan Metode Value For Money." Jurnal EMBA: Jurnal Riset Ekonomi, Manajemen, Bisnis Dan Akuntansi 2 (3): 1686-94.

Mandang, Evert Fandi, Bode Lumanauw, and Mac D.B Walangitan. 2017. "Pengaruh Tingkat Pendidikan Dan Pelatihan Terhadap Kinerja Karyawan Pada PT. Bank Rakyat Indonesia (Persero), Tbk Cabang Manado." Jurnal EMBA: Jurnal Riset Ekonomi, Manajemen, Bisnis Dan Akuntansi 5 (3): 4324-34. https://doi.org/10.35794/emba.v5i3.18427.

Mardiasmo. 2016. Akuntansi Sektor Publik. Yogyakarta.

Munti, Finta, and Heru Fahlevi. 2017. "Determinan Kinerja Pengelolaan Keuangan Desa: Studi Pada Kecamatan Gandapura Kabupaten Bireuen Aceh.” Jurnal Akuntansi Dan Investasi 18 (2): 172-82. https://doi.org/10.18196/jai.180281.

Nordiawan, D., and A. Hertianti. 2010. Akuntansi Sektor Publik. 2nd ed. Jakarta: Salemba Empat.

Onibola, Maya, Burhanuddin Kiyai, and Alden Laloma. 2017. "Kinerja Kepala Desa Dalam Pelaksanaan Pembangunan Desa Di Desa Tolok Satu Kecamatan Tompaso."

Rempowatu, Jelin, and Victorina Tirayoh. 2016. "Pengukuran Kinerja Keuangan Pada Pemerintah Kabupaten Minahasa Selatan Tahun 2011-2014." Jurnal EMBA 4 (1): 982-89.

Rofikoh, and Isniar Budiarti. 2019. "Pengaruh Insentif, Tingkat Pendidikan Dan Pengalaman Kerja Terhadap Kinerja Karyawan (Studi Kasus Pada Bagian Tata Usaha Pusat Sains Dan Teknologi Nuklir Terapan (PSTNT) - Batan)." http://library1.nida.ac.th/termpaper6/sd/2554/19755.pdf.

Ropa, Mega Oktavia. 2016. "Analisis Kinerja Keuangan Pemerintah Kabupaten Minahasa Selatan.” Jurnal EMBA 4 (2): 738-47.

Roza, Darmini, and Laurensius Arliman. 2014. "Peran Badan Permusyawaratan Desa Di Dalam Pembangunan Desa Dan Pengawasan Keuangan Desa Darmini Roza* Dan Laurensius Arliman S ** A . Latar Belakang Pembentuk Undang-Undang Dasar Negara Republik Indonesia Tahun 1945 ( UUD 1945 ) Mempertahankan Pemerintah" 4 (26): 606-24.

Saputra, Riki. 2015. "The Effects of Budgetary Participation on ManagerialPerformance Via The Organization Commitment and Job Relevant Information as Intervaning Variables. (Studies Empiris on Bengkalis)." Jurnal Online Mahasiswa Fakultas Ekonomi Universitas Riau 2 (2): 1-14.

Siregar, Fachrul Amanullah, and Fazli Syam. 2017. "Analisis Efektifitas Dan Efisiensi Pengelolaan Keuangan Desa (Studi Pada Desa Di Kabupaten Deli Serdang).” Jurnal Ilmiah Mahasiswa Ekonomi Akuntansi 2 (4): 93-106.

Sugiyono. 2015. "Metode Penelitian." Metode Penelitian.

Tambuwun, Evran Lexy, Sifrid S. Pangemanan, and Dhullo Afandi. 2014. "Analisis Kinerja Keuangan Pemerintahan Kota Manado.” Jurnal EMBA 2 (4): 81-89.

tribunnews.com. 2019. "Korupsi Dana APBDes Rp 1 Miliar, Dua Kades Di Bojonegoro Jadi Tersangka." Tribunnews.Com. 2019. https://www.tribunnews.com/regional/2019/11/05/korupsi-dana-apbdes-rp-1- 
miliar-dua-kades-di-bojonegoro-jadi-tersangka.

Triseptya, Ghaliyah Nimassita, and Harmiati Hatta. 2018. "Pengaruh Pelatihan Terhadap Kinerja Bendahara Desa" 2018: 65-69.

Utami, Tien. 2012. "Pengaruh Gaya Kepemimpinan, Kepuasan Kerja Dan Lingkungan Kerja Terhadap Kinerja Karyawan PT Primissima Di Kabupaten Sleman Daerah Istimewa Yogyakarta," 12-40.

Wahyuni, Nur. 2016. "Education \& Training Career Development Job Satisfaction Employee Performance." Journal of Education and Vocational Research 7 (1): 14-20.

Widiastutiningrum, Eva. 2017. "Peran Badan Permusyawaratan Desa (BPD) Dalam Pelaksanaan Fungsi Pengawasan Dana Desa Colo Kecamatan Dawe Kabupaten Kudus." Lib.Unnes.Ac.Id 4: 9-15. http://lib.unnes.ac.id/id/eprint/31806. 